\title{
Innovation among SMEs in Finland: The impact of stakeholder engagement and firm-level characteristics
}

\section{Hannu Littunen ${ }^{1}$ (D), Timo Tohmo (iD, Esa Storhammar}

\begin{abstract}
PURPOSE: The aim of the paper is to analyse the importance of both internal capabilities (resources) and external information sources in implementing product, process, marketing and organizational innovations aiming to maximize firm competitive advantage and create value for stakeholders. Furthermore, in particular, we examine the role of public organizations, business networks, firm size, and the industry sector, in the emergence of different types of product, process, marketing, and organizational innovations. The research was based on the typology of innovation (product, process, marketing, and organizational) adopted by the OECD. METHODOLOGY: The paper is based on data from 389 SMEs located in Finland and describes the development of a model for testing the factors that increase the innovativeness of SMEs. The logistic regression model is used as a methodology. Findings: The results show that the creation of novel products, processes and marketing innovation is connected to various external sources of information, such as fairs, the media and the internet. Moreover, the relationship between internal capabilities such as the firm's knowhow increases the marketing and organizational innovativeness of SMEs. Our results demonstrated that the creation of product innovation is positively connected to manufacturing. Furthermore, we find that the creation of novel processes and organizational innovation is related to firm size, such that firms with fewer than 20 employees (smallest firms) were concentrated among non-innovators and companies with more than 20 employees were concentrated among innovators. IMPLICATIONS FOR THEORY AND PRACTICE: The contribution of our study is to analyse to what extent various types of innovation rely on specific information sources. This study

1 Hannu Littunen, Ph.D., University of Eastern Finland, Department of Health and Social Management, P.O. Box 1627, 70211, Finland, email: hannu.littunen@uef.fi (ORCID: https://orcid.org/0000-0001-7740-5194).

2 Timo Tohmo, Ph.D, Jyväskylä University School of Business and Economics, P.O. BOX 35, 40100, Finland, email: timo. tohmo@jyu.fi (ORCID: https://orcid.org/0000-0002-1189-2257).

3 Esa Storhammar, Ph.D., Jyväskylä University School of Business and Economics, P.O. Box 35, 40100, Finland, email: esa.t.storhammar@jyu.fi (ORCID: https://orcid.org/0000-0002-4153-9761).
\end{abstract}


also provides suggestions for practice and policymakers. Contrary to expectations regarding our findings, public support organizations were not statistically significant in any innovation model. Therefore, public support organizations should develop better mechanisms to find SMEs with strong motivations to develop new products and market opportunities. ORIGINALITY AND VALUE: This paper provides a new and topical viewpoint for the literature by examining the possible factors explaining the increase in SMEs' likelihood of implementing product, process, marketing, and organizational innovations. Our study provides comprehensive information on how different stakeholders contribute to the emergence of SME innovation.

Keywords: SMEs, innovation, internal capabilities, external information sources, stakeholders, industry sector, firm size

\section{INTRODUCTION}

In the last few years, much attention has been given to the innovation activity of small and medium-sized enterprises (SMEs) (Jones-Evans et al., 2018; Lukovszki et al., 2020; Lecerf \& Omrani, 2020). Innovation activity can be seen as a prerequisite for SMEs' performance (Freel \& Robson, 2004; Keskin, 2006; Lööf \& Heshmati, 2006). As employers and producers of innovations, SMEs' performance has a significant impact on economic growth (Storey, 1994; Audretsch, 2002; Wong, et al., 2005; Rigtering et al., 2014; Ipinnaiye et al., 2017). Companies with fewer than five employees account for almost $90 \%$ of the number of Finnish companies (369 940 in 2019), contribute almost $12 \%$ of turnover ( 430246485 thousand $€$ ) and provide approximately $15 \%$ of employment (1 530 726) of Finnish firms in 2019 (OSF, 2021). Furthermore, all SMEs accounted for over half of turnover and approximately $64 \%$ of employment in Finnish firms in 2019. According to the Official Statistics of Finland (OSF, 2020), in Finland, over $60 \%$ of firms employing at least ten employees engaged in innovation activities between 2016 and $2018^{4}$. Approximately $40 \%$ of industrial firms and $34 \%$ of service sector firms made product innovations or launched new or improved products in 2016-2018.

Howells and Roberts (2000) argue that, especially for advanced industrialized countries, knowledge is one of the resources that helps companies gain a competitive advantage and creates growth and wealth. In a knowledge-based economy, increased competitiveness and innovation go hand in hand. According to Asheim et al. (2003), therefore, measures to improve the competitiveness of SMEs must focus primarily on their innovation and innovation performance.

4 Firm size classes used in the Eurostat Community Innovation Survey (CIS) are 10-49 employees (small firms), 50-249 employees (medium-sized firms) and more than 250 employees (large firms). OSF (2020) is part of the European-wide CIS survey. 
Harrison et al. (2010) found that firms that manage stakeholders devote more resources to meet the requirements of their legitimate stakeholders than would be necessary to maintain deliberate participation in the productive activities of a firm. Thus, such behaviour may disrupt the processes of value creation. However, the utility of stakeholders may also lead to firm innovativeness (see Harrison et al., 2010). In this paper, stakeholders are broadly defined as individuals or groups that may influence a firm's competitive advantage (Freeman, 1984; Jones \& Wicks, 1999; Phillips, 2003; Freeman et al., 2007; Harrison et al., 2010; Pollack et al., 2017; Jones et al., 2018; Leonidou et al., 2020).

Chang et al. (2011) argue that the innovation strategies of SMEs and large firms differ because SMEs have limited leadership skills and different internal and external operating environments. Although many studies have noted that the company must have strong internal capabilities and an advanced knowledge base to create innovation (e.g., Cohen \& Levinthal, 1990), studies to date have paid little attention to variables and indicators that can measure these internal effects. As described by Walsh and Linton (2001), industrywide competencies are needed for the success of a firm. According to this core competence perspective, obtaining a competitive advantage depends on a firm's ability to identify its managerial capabilities as well as specific technological expertise and competencies and to match these strengths with the resources necessary to gain a competitive advantage in the firm's chosen markets. Thus, if firms do not have sufficient internal capabilities, they are unlikely to identify important competencies in their environment (see, e.g., Kang \& Park, 2012; Voudouris et al., 2012).

The resource-based view (RBV) emphasizes the firm's internal factors, as the firm's strategies are considered through its internal strengths and weaknesses. Penrose (1959) argues that a firm's success is based on its ability to utilize and combine existing resources. Then, it is important both how original the resources are and how difficult it is to emulate similar resources. Furthermore, according to RBV, innovation can be seen as a valuable internal resource that can lead to firm success (Barney, 1991; Khairuddin et al., 2019). Therefore, it is important to develop and test measures of internal capabilities, especially during turbulent economic times. The question of whether different measures and indicators of internal capabilities are related to the creation of different types of innovations is also addressed in this article.

It is commonly accepted that economic development is highly dependent on the accumulation and diffusion of knowledge. However, Tödtling et al. (2009) argue that "It is unclear to what extent different kinds of innovation rely on specific knowledge sources and links." On the other hand, Amara et al. (2016) argue that four categories of knowledge assets are considered important 
in the literature to explain the firm's propensity for innovation: 1) diversity of knowledge sources; 2) knowledge creation; 3) knowledge embodied in management practices and advanced technologies and 4) knowledge embodied in the strength of ties. However, as Cassiman and Veugelers (2006) state, firms cannot rely solely on internal knowledge sourcing in their innovation activities. Thus, firms require knowledge (internal) not existing in the firm, i.e., external knowledge acquisition. Furthermore, Cohen and Levinthal (1990) state that a prior stock of knowledge, internal knowledge, plays an important role when firms scrutinize and embrace external knowledge.

Our data also consist of knowledge-intensive business service (KIBS) firms. KIBS knowledge sources can be classified as internal sources, market source information, research source information, and generally available information sources (see, e.g., Amara \& Landry, 2005; Amara et al., 2016; Rodriquez et al., 2017). Internal sources refer to knowledge from the firm, market sources refer to market-based knowledge, research sources refer to research-based knowledge and general sources refer to generally available knowledge such as scientific journal, conferences and exhibitions that are important to firms' innovation activity.

Studies analysing the relation between variety in knowledge sourcing and innovation novelty concerning manufacturing are, for example, Amara and Landry (2005), Nieto and Santamaría (2007), and Zeng et al. (2010). Rodriquez et al. (2017) studied the importance of different types of knowledge sources (information sources) for the novelty of KIBS innovation. They found evidence of a positive relation between a variety of market sources and the introduction of innovations for the firm and a negative relation between a variety of research sources and innovations for firms.

Furthermore, the OECD (2005) argues that certain types of innovation ${ }^{5}$ (product, process, marketing, and organizational) greatly affect firm performance. This evidence includes case studies using data for Finland (Varis \& Littunen, 2010), Cambodia (O'Cass et al., 2014), Greece (Kafetzopoulos et al., 2015), Brazil (Bruhn et al., 2016), Italy (Landoni et al., 2016), Spain (HervasOliver et al., 2016), Nigeria (Ilori et al., 2017), Colombia (Mejia \& Arias-Perez, 2017), Italy (De Martino et al., 2018), Portugal (Carvalho et al., 2013) and Mexico (Maldonado-Guzmán et al., 2019). Saunila (2020) suggests that the most analysed type of innovation is product innovation. She also notes that less research has been done on process innovation.

Varis and Littunen (2010) found that the emergence of product and marketing innovation is most closely linked to freely available information sources (e.g., exhibitions and fairs, the internet, the media) on SMEs in Northern Savonia. Our study augments Varis and Littunen's (2010) sample

5 OECD (2005) give full definitions of types of innovation. 
by assessing all regions in Finland. The data used in the study include 389 Finnish SMEs, of which 299 are industrial firms, 73 are KIBS firms, and 17 are firms in other sectors. The enquiry was collected through a survey and was conducted in autumn 2017 and spring 2018 through telephone interviews.

In sum, our study provides comprehensive information on how different stakeholders (various information sources) contribute to the emergence of different types of product, process, marketing, and organizational innovations in SMEs. First, we analyse the importance of internal capabilities (resources) on the adoption of new things in the firm. Second, the role of various external information sources, such as exhibitions and fairs, the internet and the media, as sources of information on reform will be examined. The extent to which different types of innovations do depend on certain data sources and links has remained largely unanswered in the innovation literature (Tödtling et al., 2009). Third, we also explore other possible information sources by analysing the weight of public organizations and other organizations in the emergence of innovations. Fourth, the focus is on the effects of different groups of firms, such as competitors, sales and distribution organizations, on the innovation process.

Thus, we believe that this paper provides a new and topical viewpoint for the literature by examining the possible factors explaining the increase in SMEs' likelihood of implementing product, process, marketing, and organizational innovations.

To delve into these matters empirically, an analysis was conducted by utilizing data collected from 389 SMEs located in Finland. Based on the sample, we employ logistic regression analysis to determine the stakeholders (various information sources) and firm-level characteristics that distinguish noninnovative and innovative companies.

The paper is organized as follows. The following chapter provides a condensed overview of the SME innovation literature, which is relevant for the current study. This section also presents the research hypotheses. The following chapter provides an introduction to the methodology used in the study, including the data and variables used. The results of the analysis are then presented and interpreted. Finally, the discussion, conclusions, and potential implications of this study are presented.

\section{LITERATURE REVIEW}

In the context of firms' innovation activities, it is important to define "innovation". Schumpeter (1939) defined innovation as a setting up of a new production function. Hagedoorn (1996) found this definition broad 
and rather vague. For example, Trott (2002) indicated that innovation is a process that involves new ideas, inventing new solutions to particular problems, and developing new markets. This study accepts the definition of innovation proposed by the OECD (2005). The widely accepted definition of technological innovation by the OECD (2005) is that innovation is, from the company's point of view, a completely new or significantly improved product, process, marketing, or organizational improvement in business practices or external relations.

The question of how to approach the stakeholders of SMEs can be considered from the viewpoint of the company's objectives and how they are achieved. A firm's objectives are formed by its stakeholders, suchlike the entrepreneur or another proprietor, the firm's employees and its financiers (Freeman, 1984; Carroll, 1993; Freeman et al., 2007). Carroll (1993) stated that an increasing number of groups belong to this category. Together with proprietors and other priority interest groups, the management of the firm is linked to the firm's next phase, competitors, local community and representatives of the government (Carroll, 1995). The task of management is thus to coordinate the expectations and requirements of the various interest groups (e.g., Eesley \& Lenox, 2006; Harrison et al., 2010). The idea from stakeholder theory is that various groups that have mutual inputs to a firm interact with each other and make its operations possible. We adopt in our study the view used by Freeman (1984) and Tang and Tang (2012) that all individuals or groups are defined as stakeholders who can influence the achievement of the firm's goals or who are affected by it. Thus, stakeholders may be crucial sources in innovation processes (Vrontis et al., 2017; Santoro et al., 2018).

Grama-Vigouroux et al. (2020) argue that stakeholder engagement strengthens organizational competencies in knowledge retrieval, retention, and utilization. According to Harrison et al. (2010), activities with the firm's interest groups increase a firm's knowledge and thus increase its ability to innovate. Similarly, Sawang and Unsworth (2011) found that the weight of external stakeholders is pushed to the innovativeness of SMEs. According to the study of Bridoux and Stoelhorst (2014), primary stakeholders, i.e., customers and owners, create value and competitive advantage and make it easier to manage core competencies and innovation orientation in firm operations (see also Prahalad \& Hamel, 1990; Walsh \& Linton, 2001).

Llerena and Oltra (2002) distinguished between internal and external learning to characterize the innovation strategies of firms (e.g., Malerba 1992; Peeters \& van Pottelsberghe de la Potterie, 2006). Internal learning is related mainly to formalized activities, i.e., knowledge is generated through formalized internal sources such as R\&D. In turn, external learning is related to 
information from external sources such as public research and dissemination. Numerous studies have provided strong theoretical support for the utility of a firm's internal capabilities (Zahra \& Covin, 1993; Lumpkin \& Dess, 2001; Kreiser et al., 2002; Tang et al., 2008; Saunila 2016, 2020). Hervas-Oliver et al. (2011) studied Spanish low- and medium-low-tech firms in 2015 and 2016, which were mainly SMEs, and found that firms with more internal resources had better possibilities for cooperating and accessing external knowledge flows. Thus, internal capabilities, networking capabilities, and the use of external information sources may be interconnected in complex ways.

In contrast, the role of external information sources in companies' ability to innovate has been less studied, especially in Finland. Leiponen (2012) found with Finnish $\mathrm{ClS}$ data that manufacturing and service firms benefit from the scope of external knowledge acquisition strategies. Furthermore, Leiponen and Helfat (2010) argue that by using a larger number of complementary knowledge sources, firms may increase their probability of obtaining useful knowledge that leads to innovation.

Sources of useful information are supposed to vary between different types (process, product, marketing, and organizational) of innovation (Freel \& de Jong, 2009; Varis \& Littunen, 2010). Thus, SMEs' innovation performance is supposed to be shaped along with internal capabilities and the use of external information sources. From the theoretical starting point mentioned above, we formulate the following research hypotheses:

H1: Higher internal capabilities of a firm increase SMEs' likelihood of implementing product, process, marketing and organizational innovations.

H2: Companies using various types of external information sources in their innovation process have an increased likelihood of innovating through product, process, marketing and organizational innovations.

The resources and networking opportunities of SMEs are often limited. According to Freel (2003), supplementing and complementing SMEs with limited resources on innovation processes and business cooperation have been of interest since the late 1980s and 1990s. Freel (2003) provides a detailed discussion on the importance of extending the knowledge base and risk-sharing offered by, e.g. universities and public agencies, on firms' innovation capacity. He concludes that innovative small firms are more likely to be associated with public sector support, ministries, or trade support organizations than noninnovative firms. Furthermore, the role of universities and public research institutes as sources of new knowledge is 
also emphasized, e.g., by Cassiman et al. (2009), Belderbos et al. (2016), and Caloghirou et al. (2021). However, universities and public research institutions are not the only public organizations offering innovation policy instruments to SMEs' innovation processes.

Policy instrument systems can generally be considered complex due to a large number of support instruments. Public policy instruments are defined as a set of techniques that authorities use to support and implement social change (Vedung, 1998). Thus, policy instruments concerning innovation policy are supposed to foster innovation, including instruments offered by universities and public research institutions. Borrás and Edquist (2013) categorize policy instruments into three groups: regulatory instruments (legal tools, rules, directives), economic and financial instruments (subsidies, loan guarantees, promotions, etc.) and soft instruments (recommendations, agreements, relations, partnerships). Soft instruments have become more popular over the years, which means that, according to Borrás and Edquist (2013), the role of governments has changed from providers and regulators towards coordinators or facilitators.

To meet the limited resources of companies, regional developers and the public sector have developed innovation-related services for SME innovation processes. Boter and Lundström (2005) analysed how Swedish SMEs use existing support services and found low participation rates on available support services. Olmos-Penuela et al. (2017) found that Spanish SME firms with formal plans for innovation benefit from cooperation with public research organizations. Cravo and Piza (2019) found in their meta-analysis that in low- and middle-income countries, business support interventions relating to formalization, business environment, exports, clusters, training, access to credit, technical assistance and innovation, improve SME performance. Furthermore, Mole et al. (2017) found that firms with more than nine employees in the UK were more likely to access business support than microfirms. Moreover, Mole et al. (2017) found sectoral differences in accessing support and intention to growth to be related to support-seeking behaviour. Thus, the evidence on the business-support seeking behaviour of SMEs is not deterministic or consistent. The purpose of our study is to determine whether SMEs benefit from the knowledge offered by public support organizations in innovation processes. Derived from the above discussion, the third research hypothesis is proposed:

H3: SMEs that use services from public support organizations are more likely to implement product, process, marketing and organizational innovations. 
The importance of networks in firms' innovation processes has grown during the last few decades (Hagedoorn, 2002; Zeng, Xie \& Tan, 2010; Belderbos et al., 2018). Along with the growing importance of networks, research into them has also increased. As a consequence, a vast number of studies have analysed the relation between networks or cooperation and a firm's innovation performance (Kaufmann \& Tödtling, 2002; Tether, 2002; Becker \& Dietz, 2004; Doloreux, 2004; Dickson et al., 2006; Nieto \& Santamaría, 2007; Zeng et al., 2010). Nieto and Santamaria (2007) studied Spanish manufacturing firms and found that technological networks are crucial to achieving product innovations with a higher degree of novelty value. Suppliers, clients and research organizations had a positive impact on innovation novelty. Contrary, competitors' influence was negative. Furthermore, Zeng et al. (2010) studied 137 Chinese manufacturing SMEs and found a positive relation between innovation performance and interfirm cooperation, intermediary institutions and research organizations. Suppliers, customers and other firms seem to be more important organizations in innovation processes than governments, universities, or research institutes. Thus, networks could be seen as a way to complement a firm's internal resource base to achieve more successful innovation processes.

Rosenzweig (2017) argues that innovation networks enable firms to access external information sources. Saastamoinen et al. (2018) state that networks with other firms is related to the innovation performance of SMEs. They conclude that while developing new products for the public sector, SMEs should emphasize networks with other firms and place less emphasis on networks with public or private R\&D actors. Hossain and Kauranen (2016) state that SMEs are forced to keep several networks manageable because they have limitations on various resources, in addition to which the time available for networking is limited. As a consequence, combining different knowledge in innovation processes may be related to the emergence of innovation. The fourth research hypothesis is formulated as follows:

H4: Companies with denser networks are more likely to implement product, process, marketing and organizational innovations.

\section{Innovation and firm-level characteristics}

According to the $\operatorname{OECD}(1997,2005,2018)$, innovation activity varies significantly between companies of different sizes. Moreover, Kirchhoff et al. (2013) argue that only a slight proportion of small firms will grow into medium-sized firms. The most prominent job creators are technology firms with a high degree of innovation and rapid growth at the same time. Several 
studies on innovation processes have noted that firm size may affect SMEs' innovation activities (Rogers, 2004; Vaona \& Pianta, 2008; Park et al., 2010; Demirel \& Mazzucato, 2012; Deschryvere, 2014; Antonelli \& Scellato, 2015; Littunen \& Huovinen, 2020).

SME resources are typically scarce, which may influence their innovation activities. Woschke et al. (2017) reviewed 17 studies to determine the relation between resource scarcity and innovation. Firms were found to need resources to seek new opportunities. In contrast, for some firms, constraints were found to affect positively. As a consequence, the relation between the scarcity of resources and innovations is contradictory. Thus, firm size is supposed to affect the availability of scarce resources. However, our data do not address issues related to the scarcity of firm resources, and we are not able to distinguish the relationship between different innovation types and SME resource scarcity.

The relationship between firm size and innovation activity has proven to be contradictory. Among others, Pavitt (1984), Vaona and Pianta (2008), Park et al. (2010), and Deschryvere (2014) suggest that the size of a firm can be linked to its innovation processes. In contrast, Arvanitis (1997) argues that there is no link between innovation and firm size. The relationship between firm size and innovation orientation is examined by Lafore $^{6}(2008)$, who discovered that firm size and strategic orientation are associated with innovation performance. Laforet (2008) found that the firms that had adopted a prospector strategy were more innovative and market-oriented than those pursuing a defender strategy (see also Ghosh et al., 2001). However, Arvanitis (1997) received contradictory results to some extent, as, according to him, the size of a firm does not affect the innovativeness of the firm. No final consensus has been reached, despite the number of studies on the subject, but more research is needed on the nature of the links between firm size and innovation. Based on the abovementioned theoretical starting points, we formulate the following fifth research hypothesis:

\section{H5: A larger firm size increases the likelihood of implementing product, process, marketing and organizational innovations.}

There exists a great deal of research that connects the industry sector of SMEs, which is crucial for the innovativeness and performance of a firm (e.g., Tether, 2005; Howells, 2005; Prajogo, 2006; Mansury \& Love, 2008; JiménezJiménez \& Sanz-Valle, 2011; Segarra \& Teruel, 2014; Littunen \& Huovinen, 2020). Negassi et al. (2019) argue that firms in different industries differ considerably

6 According to her, within the SME population, medium-sized firms are proactive 'prospectors' that habitually search for opportunities and utilize analysis in the formulation of their competitive strategy, whereas the smaller firms are reactive 'defenders' whose activities are more short-term and reactive to the observations made of the environment 
from the point of view of innovation strategies, as industries offer different opportunities as well as constraints for the organization of innovation activities by firms. Earlier studies have found a relation between the industry sector and innovation activity and firm performance (Beaudry \& Swann, 2009; Antonelli \& Scellato, 2015). Despite the importance of innovations, very little is known about their origins, development mechanisms and diffusion in different operating environments, which are shaped by the specifics of the industry.

For instance, Littunen and Huovinen (2020) pointed out that the creation of product and process innovation is positively related to the manufacturing industry, but then the creation of marketing innovations is linked to the field of trade. In turn, Vega-Jurado et al. (2008) stated that innovation factors vary in the industry and the novelty of newly developed products. Similarly, Segarra and Teruel $(2014$, p. 819$)$ found that R\&D intensity has a positive and statistically significant sign for manufacturing firms. In contrast, R\&D intensity does not affect the growth of service firms. Similar results were also obtained by Beaudry and Swann (2009), who analysed industrial cluster effects in the UK; they found the strongest cluster effects on growth in manufacturing, manufacturing-related (agriculture; mining; construction; extraction of crude petroleum and natural gas, and related services) and infrastructure (electricity, gas, steam and hot water supply; air transport, water transport; education) sectors. However, cluster effects on firm growth were weaker in services (retail trade; insurance and pension funding; activities auxiliary to financial intermediation; other business activities). On the other hand, according to Cainelli et al. (2004) and Leiponen (2005), innovation activity is strongly linked in service firms (see also Henrekson \& Johansson, 2010).

Our data consist also of KIBS firms. The KIBS sector is commonly regarded as one of the most important drivers of economic growth and technological change. KIBS can be seen as playing two distinct roles (Shearmur \& Doloreux, 2019): 1) they act as providers of intermediation services to innovators that drive innovation in their client companies, and 2) KIBS act as innovators introducing internal innovations, providing mostly highly qualified workplaces and contributing to economic growth (see also Muller \& Zenker, 2001).

However, Weerawardena et al. (2006, p. 43) argue that industry does not have a uniform relation to a firm's strategies of knowledge acquisition. They also call for more study of the internal factors that guide a firm's acquisition of information through internal sources. Therefore, derived from the above discussion, the sixth research hypothesis is proposed:

H6: Operating in the manufacturing sector increases the likelihood of SMEs implementing product, process, marketing and organizational innovations. 


\section{METHODOLOGY}

\section{Data and sample}

The data used in the study were collected through a survey of Finnish SMEs. Samples from SMEs of different sizes and regions were purchased from Statistics Finland. The survey was conducted through telephone interviews with industrial SMEs and KIBS-based companies. Although the firms in Statistics Finland data were classified as industrial or KIBS firms, some of the enterprises interviewed still turned out to be other types of firms (e.g., service firms other than KIBS). The telephone interviews were conducted by a surveying company that specializes in this method, and interviewers were trained in interview techniques. In addition, the completed questionnaire was pretested as a telephone interview with firms. The data consisted of 389 SMEs, 299 industrial enterprises and 73 KIBS enterprises, and 17 firms in other sectors. Data were collected by a telephone survey in autumn 2017 and spring 2018.

The OECD (2018) argues that the innovation activities of firms differ by size. As a consequence, we used firm size to construct strata. The size categories are determined by the number of employees in the SMEs as follows: less than 5 employees, 5-9 employees, 10-49 employees, and 50 or more employees. For the firm interviews, the sample was also stratified by firm location. Regionally, the companies were located in six regions: 1) the Helsinki region, 2) the Oulu, Vaasa and Seinäjoki regions, 3) the Tampere and Turku regions, 4) the Jyväskylä, Kuopio and Joensuu regions, 5) the Lahti, Kouvola, Kotka and Lappeenranta regions, and 8) other than the abovementioned regions. The companies replied to the telephone interviews very well, and there were only a few refusals. In the stratified sample, a company that refused was replaced by a new company. According to the OECD (2018), there are no clear boundaries for high, moderate, or low response rates. However, the response rate of our enquiry exceeded $70 \%$, which could be used as a rule of thumb as a high response rate (OECD, 2018). Thus, we believe that our sample describes the target population, SMEs in Finland, well, and the results are generalized to the target population.

Respondents of the inquiry were entrepreneurs and professionals (SMEs usually do not have employees, such as R\&D managers, who are responsible for developing innovation). Our study used a structured questionnaire that included questions that were operationalized from the theoretical literature, utilized in previous innovation research, and new questions related to the theme. Thus, items and questions are based on a wide range of literature, including the $\operatorname{OECD}(1997,2005)$. We strove to make a logically constructed questionnaire with clear definitions and instructions so that respondents 
understood exactly what had been asked. We used questions that dealt with issues such as the business environment, networks, innovation strategies, and innovation activities. As a result, the data cover the broad scope of SME growth, performance, and innovation. The dependent variable has a binary outcome, so probability models and binary logistic regression are well suited for analysis. However, logistic regression is not the right method for measurements with continuous outcomes. Tansey et al. (1996) demonstrate the advantages and disadvantages of logistic regression analysis. In logistic regression analysis, data points should be independent of other data points. As a result of the dependence of different data points, the model will overweight those observations. One example of such a study is matched pairs design which matches a drug-taker with a similar individual who is taking a placebo. Perhaps the major limitation of the model is the linearity assumption between the independent and dependent variables. However, the advantages of the logistic regression model are remarkable: 1 ) it does not need distribution assumptions in feature space, 2) it is relatively easy to implement, 3) the results are well interpreted, and 4) as a result, it gives the size of the coefficients and their direction, i.e., how appropriate an independent variable is and is the sign of the coefficient positive or negative; 5 ) it can be extended to outcomes with three or more categories, 6) overfitting is not a big problem, and 7) it can be regarded as a model of good accuracy.

Innovation activity is suggested to vary considerably between firms of different sizes (OECD, 1997, 2005). Furthermore, the OECD has defined the types of innovation in four categories: 1) production, 2) process, 3) marketing, and 4) organization as innovation. In the survey, we followed the OECD guidelines, and the sample was stratified according to the size of the enterprises. The innovations were also typed according to the OECD specification. Overall, it can be argued that the surveyed firms represent rather well the typical small companies that make up the majority of companies in Finland (Statistics Finland, 2014). Over 77\% of the companies were small enterprises with fewer than twenty employees (Table 1).

The European Union (2020) defines small firms as having fewer than 50 employees and medium-sized firms as firms with fewer than 250 employees. Microenterprises, on the other hand, employ fewer than 10 people. However, the majority of innovation surveys tend to underrepresent or completely ignore the population of the smallest enterprises, especially microenterprises. Furthermore, Kirchhoff et al. (2013) argue that only a slight proportion of small firms will grow into medium-sized firms. Based on the abovementioned starting points, our study highlights the innovation performance of the smallest firms with fewer than 5 employees relative to larger firms. 
The size distribution in our study is based on Statistics Finland firm size distribution: 1) Fewer than 5 employees, 2) 5-9 employees, 3) 10-19 employees, 4) 20-49 employees, 5) 50-99 employees and 6) 100-249 employees. This enables us to compare the smallest firms, which have been largely overlooked in innovation studies, with larger SMEs. For the analyses, we have combined the categories so that the categories to be analyzed are 1) Less than 5 employees, 2) 5-19 employees, 3) 20 employees or more. The size distribution of the sample firms provides an interesting starting point for the current study.

Finnish industry is dominant in the sample (76.9\%). Almost one-fifth of the enterprises were KIBS firms. Typically, KIBS firms require highly skilled employees. Miles et al. (1995) divided the KIBS industry into two parts: 1) I-KIBS, which are traditional expert services, and 2) II-KIBS, which are based on new technologies. In our study, we do not divide KIBS companies into two main groups because of the size of the sample. Table 1 presents the sample size and industry distribution, and in Appendix 1, sectors included in the KIBS sector are shown.

Table 1. Distribution of the sample by industry and company size

\begin{tabular}{lllll}
\hline Industry & $\begin{array}{l}\text { Less than } \\
\mathbf{5} \text { employees }\end{array}$ & $\mathbf{5 - 1 9 \text { employees }}$ & $\begin{array}{l}\text { 20 employees } \\
\text { or more }\end{array}$ & $\begin{array}{l}\text { Total no. of } \\
\text { firms }\end{array}$ \\
\hline Manufacturing & 127 & 94 & 78 & $299(76.9 \%)$ \\
KIBS firms & 52 & 15 & 6 & $73(18.8 \%)$ \\
Other industry & 5 & 7 & 5 & $17(4.3 \%)$ \\
Total & $184(47.3 \%)$ & $116(29.8 \%)$ & $89(22.9 \%)$ & $389(100.0 \%)$ \\
\hline
\end{tabular}

\section{Variables and measures}

The OECD (2005) gives full definitions of types of innovation. Product innovations relate to entirely new products or services as well as significant improvements of existing products. Process innovation is the case when a company makes significant changes in production and delivery methods. Changes in the organization's internal business practices or business practices in the company's external relations refer to organizational innovations. Marketing innovations, in turn, include the introduction of new marketing methods as well as changes in product promotion and placement.

Our study uses the above OECD typology and analyses how various information sources (individuals or groups that may influence firms' competitive advantage, stakeholders) and firm-level characteristics (size and industrial sector) are connected to SMEs' likelihood of implementing the product, process, marketing and organizational innovations. Our main interests are in internal capabilities, use of external information sources, use 
of services of public support companies, business network density, firm size, and the industrial sector. Definitions of variables are shown in Table 2.

Table 2. Variable definitions

\begin{tabular}{|c|c|c|}
\hline Dependent variables & Definition & Scale of measurement \\
\hline $\begin{array}{l}\text { Product/ } \\
\text { process/ } \\
\text { marketing/ } \\
\text { organizational } \\
\text { innovation } \\
\end{array}$ & $\begin{array}{l}\text { Variable indicating whether a firm } \\
\text { has introduced a completely new or } \\
\text { significantly improved innovation(s) } \\
\text { within three years before the inquiry. } \\
\text { Dummy variable }\end{array}$ & $\begin{array}{l}1=\text { Innovation } \\
0=\text { Otherwise }\end{array}$ \\
\hline \multicolumn{3}{|l|}{ Independent variables } \\
\hline Internal & $\begin{array}{l}\text { The importance of a firm's internal } \\
\text { capabilities (sum-variable) } \\
\text { - Company expertise (know-how) } \\
\text { - The ability of the firm to change its } \\
\text { operations } \\
\text { - Training and education for employees } \\
\text { - Employee initiatives } \\
\text { - How work is organized (e.g., } \\
\text { - teamwork, job rotation) } \\
\text { - Organizational communication within } \\
\text { - Spo company } \\
\text { the company } \\
\text { - Shared leisure activities and social } \\
\text { events }\end{array}$ & $\begin{array}{l}\text { All sub-variables were } \\
\text { measured on the scale } \\
\text { 1-5 (Likert scale) and } \\
\text { then summed up. }\end{array}$ \\
\hline Diffext & $\begin{array}{l}\text { The importance of various external } \\
\text { information sources (sum-variable) } \\
\text { - Fairs and exhibitions } \\
\text { - Internet } \\
\text { - Patent databases } \\
\text { - Media } \\
\text { - Professional literature } \\
\text { - Educational meetings } \\
\text { - Friends of the entrepreneur } \\
\text { - Participation in development projects }\end{array}$ & $\begin{array}{l}\text { All sub-variables were } \\
\text { measured on the scale } \\
\text { 1-5 (Likert scale) and } \\
\text { then summed up. }\end{array}$ \\
\hline Pubsupp & $\begin{array}{l}\text { The importance of using services of } \\
\text { public support organization (sum- } \\
\text { variable) } \\
\text { - The local offices of government } \\
\text { located in regions (Centre for } \\
\text { Economic Development, Transport } \\
\text { and the Environment) } \\
\text { - The Federation of Finnish } \\
\text { Enterprises/The Confederation of } \\
\text { - Finnish Industries } \\
\text { - Industry organization } \\
\text { - University } \\
\text { - Other educational institution } \\
\text { - Tesearch institutes }\end{array}$ & $\begin{array}{l}\text { All sub-variables were } \\
\text { measured on the scale } \\
\text { 1-5 (Likert scale) and } \\
\text { then summed up. }\end{array}$ \\
\hline
\end{tabular}




\begin{tabular}{|c|c|c|}
\hline Dependent variables & Definition & Scale of measurement \\
\hline \multirow[t]{2}{*}{ Network } & $\begin{array}{l}\text { The importance of business network } \\
\text { relations (sum-variable) } \\
\text { - Clients (customers) } \\
\text { - Rival (competitors) } \\
\text { - Sales and delivery organization } \\
\text { - Subcontractors and suppliers } \\
\text { - Business service companies } \\
\text { (and consultants) } \\
\text { - Accounting firms }\end{array}$ & $\begin{array}{l}\text { All sub-variables were } \\
\text { measured on the scale } \\
\text { 1-5 (Likert scale) and } \\
\text { then summed up. }\end{array}$ \\
\hline & $\begin{array}{l}\text { The size of the firm (employees; } \\
\text { categorical variable) }\end{array}$ & \\
\hline Size (1) & & $1=<5,0=>4$ \\
\hline Size (2) & & $1=5-19,0=<5$ and $>19$ \\
\hline \multirow[t]{2}{*}{ Size } & & $0=<5,1=5-19,2=>19$ \\
\hline & $\begin{array}{l}\text { The industry of the firm (categorical } \\
\text { variable) }\end{array}$ & \\
\hline Industry (1) & & $\begin{array}{l}0=\text { KIBS firms and } \\
\text { others, } \\
1=\text { manufacturing, }\end{array}$ \\
\hline Industry (2) & & $\begin{array}{l}0=\text { manufacturing and } \\
\text { KIBS firms, } 1=\text { others }\end{array}$ \\
\hline Industry & & $\begin{array}{l}0=\text { manufacturing, } \\
1=\text { others, } \\
2=\text { KIBS firms }\end{array}$ \\
\hline
\end{tabular}

It is expected that firms' various information sources connected to the creation of innovations may vary depending on the type of innovation. Therefore, separate models have been created for different types of innovation. The dependent variable used in this study is the introduction of product, process, marketing, and organizational innovations in the firm. In the models, we look at a total of six explanatory variables to analyse different aspects of various information sources (stakeholders). On a five-point Likert scale ranging from 1 (strongly disagree) to 5 (strongly agree), respondents were asked to give their opinions on a number of statements concerning the company's various information sources. We combine several different variables into sum variables to improve the validity and reliability of the study. Four sum variables were identified (see also Varis \& Littunen, 2010): internal capability factor (eight items), external information sources (eight items), public support organizations (seven items), and business network relations (six items). Regarding firm-level characteristics, two categorical variables were employed to measure firm size as well as the industry of a firm. 
In the present study, a dummy variable, Size (1), equals one if a firm employs fewer than 5 employees and zero if there are more than 4 employees. Additionally, a dummy variable for "middle-sized" firms, Size (2), was used, which equals one if a firm has 5-19 employees and a value of zero otherwise. Variable Size indicates whether the overall variable is statistically significant. However, Size is not a variable in the model, which is why there is no coefficient listed. Thus, variables that code for Size are included in the regressions (Size (1) and Size (2))

A dummy variable, Industry (1), equals one if a firm operates in the manufacturing sector and zero otherwise (KIBS firms and others). Additionally, a dummy variable, Industry (2), was used, which equals zero if a firm operates in manufacturing or KIBS sectors and a value of one otherwise. Industry is not a variable in the model, which is why there is no coefficient listed. See Table 2 for a description of the variables used.

\section{RESULTS}

In our data, 331 firms engage in innovation activities (Table 3). Fifty-six firms were non-innovative firms without any product, process, marketing or organizational innovations. Most common innovations related to product innovations. In contrast, organizational innovations were less common since approximately $37 \%$ of all firms had made changes to the organization that could be regarded as organizational innovations.

Table 3. Distribution of the sample by industry and company size

\begin{tabular}{llllll}
\hline $\begin{array}{l}\text { Distribution } \\
\text { of firms }\end{array}$ & $\mathbf{n}$ & $\begin{array}{l}\text { Product } \\
\text { innovations } \\
\mathbf{n}(\%)\end{array}$ & $\begin{array}{l}\text { Process } \\
\text { innovations } \\
\mathbf{n}(\%)\end{array}$ & $\begin{array}{l}\text { Marketing } \\
\text { innovations } \\
\mathbf{n}(\%)\end{array}$ & $\begin{array}{l}\text { Organizational } \\
\text { innovations } \\
\mathbf{n}(\%)\end{array}$ \\
\hline $\begin{array}{l}\text { Number of } \\
\text { firms that } \\
\text { has not made }\end{array}$ & $120(31 \%)$ & $135(34.9 \%)$ & $205(52.7 \%)$ & $241(62.4 \%)$ \\
\hline $\begin{array}{l}\text { innovations } \\
\text { Number of } \\
\text { firms that } \\
\text { has made } \\
\text { innnovations }\end{array}$ & $267(69 \%)$ & $252(65.1 \%)$ & $180(46.8 \%)$ & $145(37.6 \%)$ \\
\hline $\begin{array}{l}\text { Has made } \\
\text { all types of } \\
\text { innovations }\end{array}$ & $\begin{array}{l}76 \text { of 331 } \\
\text { firms }\end{array}$ & & & & \\
\hline Total & $387(100 \%)$ & 387 & 387 & 385 & 386 \\
\hline
\end{tabular}

Notes: 56 of 387 firms have not made innovations at all (non-innovative firms). 331 firms have made product, process, marketing or organizational innovations. 
Descriptive statistics for each of four continuous explanatory sum variables are shown in Table 4. Additionally, the reliability values of the sum variables (continuous) are shown. The descriptive statistics in Table 4 are presented for all firms. However, all firms $(\mathrm{N}=389)$ did not answer all questions, which is why $\mathrm{n}$ varies by sum variable.

Table 4. Descriptive statistics of continuous independent variables and reliability coefficients (Cronbach's alphas) of the independent sum-variables

\begin{tabular}{lllll}
\hline $\begin{array}{l}\text { Independent } \\
\text { variables }\end{array}$ & $\begin{array}{l}\text { Number of } \\
\text { firms }\end{array}$ & Mean & Std. dev. & Alpha \\
\hline Internal & 324 & 2.8021 & 0.7801 & 0.865 \\
Diffext & 374 & 2.5866 & 0.7211 & 0.790 \\
Pubsupp & 372 & 1.6897 & 0.6706 & 0.831 \\
Network & 365 & 2.5543 & 0.6525 & 0.663 \\
\hline
\end{tabular}

The descriptive evidence in Table 4 suggests that the introduction of innovation may be strongly emphasized by internal capabilities (Internal). This suggestion is in line with the previous RBV literature and encourages us to further analyse the factors that contribute to the creation of products, processes, marketing, and organizational innovation. On the other hand, the least importance is given to the creation of innovation by public organizations (Pubsupp). Standard deviations are quite low regarding all the variables; thus, these variables are not on the skew distribution. In addition, the normal distribution of explanatory variables is not expected, unlike in linear regression analysis (see, e.g., Hosmer \& Lemeshow, 2000). The reliabilities of the variables describing firms' various information sources range from 0.663 to 0.865 (see Cronbach, 1951). Nunally (1978) considered 0.5 to be the lower limit of acceptability (see also Tavakol \& Dennick, 2011). According to the results of Cronbach's alpha, all scales were completely internally consistent (ibid), i.e., confidence values were significantly higher than 0.5 .

Correlations of variables are shown in Appendix 2. Correlations are mainly statistically significant, showing that explanatory variables are connected to different types (product, process, marketing, and organizational) of innovation.

\section{Multivariate analysis}

The results relating to SME product innovations are presented in Table 5. The estimated model was highly significant (model Chi-square $=0.000$ ). Our model classifies observed observations into two groups extremely well. As a consequence, $75.7 \%$ of the total number of observations was correctly classified using a logistic regression model. 
Table 5. The importance of stakeholders and firm-level characteristics related to product innovation in SMEs. Logistic regression model

\begin{tabular}{llll}
\hline Explanatory variable & Coefficient & Standard error & Significance \\
\hline Internal & 0.110 & 0.239 & 0.646 \\
Diffext & 1.109 & 0.303 & $0.000^{* * *}$ \\
Pubsupp & -0.270 & 0.307 & 0.380 \\
Network & -0.167 & 0.307 & 0.587 \\
Size & & & 0.226 \\
Size (1) & -0.601 & 0.411 & 0.143 \\
Size (2) & -0.100 & 0.411 & 0.808 \\
Industry & & & $0.015^{* *}$ \\
Industry (1) & 0.892 & 0.359 & $0.013^{*}$ \\
Industry (2) & 2.284 & 1.104 & $0.039^{* *}$ \\
Constant & -1.643 & 0.931 & $0.078^{*}$ \\
\hline
\end{tabular}

Notes: * significant at $10 \%$; * significant at $5 \%$; *** significant at $1 \%$.

Partial classification rates (\%): firms with new product innovation $(\%)=94.8$; other firms $(\%)=24.1$

Model Chi-square $=0.000 ; n=292 ; \mathrm{df}=8$, total classification rates $(\%)=75.7$

Dependent variable: introduction of an innovation by a firm: $0=$ no innovation, $1=$ innovation

The logistic regression model shows that Diffext, Industry (1) and Industry (2) were statistically significant variables. Various external information sources, such as fairs, the media and the internet, increase SMEs' likelihood of creating product innovation ( $\mathrm{H} 2$ supported). A strong motivation to develop new products and to seek new opportunities broadly from various external sources is linked to the innovativeness of SMEs, and there are differences between innovative and noninnovative SMEs (see, e.g., March, 1991; Eesley \& Lenox, 2006; Varis \& Littunen, 2010; Harrison et al. 2010; Littunen \& Rissanen, 2015). This finding suggests that the entrepreneurs who develop products in their small firms do not think of their firms strategically but are flexible to changes in the environment (see, e.g., Vos, 2005). However, in contrast to previous studies, the introduction of product innovation related to the internal capabilities of a firm was not found to be significant (e.g., Vega-Jurado et al., 2008; Kang \& Park, 2012; Voudouris et al., 2012; Landoni et al., 2016), and $H 1$ cannot be accepted.

The results confirm that the creation of product innovation is positively connected with manufacturing ( $H 6$ supported). This result is similar to many other studies (e.g., Prajogo, 2006; Beaudry \& Swann, 2009; Jiménez-Jiménez \& Sanz-Valle, 2011; llori \& Lamal, 2017).

Regarding firms' process-related innovative activity, the logistic regression model (Table 6) was highly significant (model Chi-square=0.000). 
Our model classifies observed observations into two groups extremely well. As a consequence, $73.5 \%$ of the total number of observations was correctly classified using a logistic regression model.

Table 6. The importance of stakeholders and firm-level characteristics related to process innovation in SMEs. Logistic regression model

\begin{tabular}{llll}
\hline Explanatory variables & Coefficient & Standard error & Significance \\
\hline Internal & 0.266 & 0.223 & 0.232 \\
Diffext & 0.540 & 0.267 & $0.043^{* *}$ \\
Pubsupp & 0.215 & 0.295 & 0.465 \\
Network & -0.049 & 0.294 & 0.868 \\
Size & & & $0.053^{*}$ \\
Size (1) & -0.959 & 0.412 & $0.020^{* *}$ \\
Size (2) & -0.845 & 0.404 & $0.036^{* *}$ \\
Industry & & & 0.261 \\
Industry (1) & 0.571 & 0.350 & 0.102 \\
Industry (2) & 0.365 & 0.706 & 0.606 \\
Constant & -1.281 & 0.896 & 0.153 \\
\hline
\end{tabular}

Notes: ${ }^{*}$ significant at $10 \% ;{ }^{* *}$ significant at $5 \% ; * * *$ significant at $1 \%$.

Partial classification rates (\%): firms with new process innovation $(\%)=92.5$; other firms $(\%)=32.3$

Model Chi-square $=0.000 ; n=294 ; \mathrm{df}=8$, total classification rates $(\%)=73.5$

Dependent variable: introduction of an innovation by a firm: 0 = no innovation, $1=$ innovation

Note: Negative value means that with a dummy value $=1$, the coefficient is negative, i.e., a value of zero has a greater effect. Size (1) obtains the value 1 when there are fewer than 5 employees, and size (2) = 1 when there are 5-9 employees.

The logistic regression model showed that the statistically significant variables were Diffext, Size (1), and Size (2). In line with the results of the product innovation model, the results of the process innovation model showed that various external information sources contribute positively to the creation of process innovation in SMEs (H2 supported). This finding supports several studies in which an entrepreneur utilizes a variety of sources in the creation of process innovation (e.g., Freel, 2003; Amara \& Landry, 2005). The results tie well with previous studies wherein the creation of process innovation was linked to the size of firms (see, e.g., Van Dijk et al., 1997; Laforet, 2008; Damanpour, 2010). According to the results, process innovation was stronger in large (=over 20 employees) firms than in small (=less than 20 employees) firms ( $H 5$ supported). This result is partly similar to Abel-Koch et al. (2015), who found in Germany that manufacturing SMEs with more than 10 employees introduced more process innovations between 2010 and 2012 than smaller firms in the construction, wholesale and retail or services sectors. 
In addition, a logistic regression analysis was performed to compare various information sources (stakeholders) and firm-level characteristics associated with the creation of marketing innovations (Table 7). The estimated model was highly significant (model Chi-square $=0.000$ ). Our model classifies observed observations into two groups fairly well. As a consequence, $63.0 \%$ of the total number of observations was correctly classified using a logistic regression model.

The logistic regression model shows that the Internal and Diffext variables were statistically significant ( $\mathrm{H} 1$ and $\mathrm{H} 2$ supported). The findings are directly in line with previous findings (e.g., Cohen \& Levinthal, 1990; Kreiser et al. 2002; Tang et al., 2008; Petrou \& Daskalopoulou, 2013) that internal capabilities, such as a firm's know-how, have an effect on the firm's innovativeness, that is, in this case, on the creation of marketing innovation. In the context of the stakeholder framework, primary stakeholders as entrepreneurs themselves, firm owners and employees are, according to the results, most important in the marketing innovation process (see, e.g., Freeman et al., 2007; Harrison et al., 2010). In line with the product and process innovation model, the results for marketing innovation showed that various external information sources, such as the internet, entrepreneurs' friends and participation in development projects, have a positive relation to the creation of marketing innovation in SMEs.

Table 7. The importance of stakeholders and firm-level characteristics related to marketing innovation in SMEs. Logistic regression model

\begin{tabular}{llll}
\hline Explanatory variables & Coefficient & Standard error & Significance \\
\hline Internal & 0.429 & 0.208 & $0.039^{* *}$ \\
Diffext & 0.498 & 0.240 & $0.038^{* *}$ \\
Pubsupp & -0.153 & 0.252 & 0.545 \\
Network & 0.312 & 0.267 & 0.243 \\
Size & & & 0.619 \\
Size (1) & -0.166 & 0.346 & 0.632 \\
Size (2) & -0.320 & 0.329 & 0.330 \\
Industry & & & 0.803 \\
Industry (1) & -0.037 & 0.340 & 0.914 \\
Industry (2) & -0.422 & 0.660 & 0.523 \\
Constant & -2.751 & 0.854 & $0.001^{* * *}$ \\
\hline
\end{tabular}

Notes: ${ }^{*}$ significant at $10 \% ;{ }^{* *}$ significant at $5 \% ;{ }^{* * *}$ significant at $1 \%$.

Partial classification rates (\%): firms with new marketing innovation $(\%)=58.0$; other firms $(\%)=67.8$

Model Chi-square $=0.000 ; n=292 ; \mathrm{df}=8$, total classification rates $(\%)=63.0$

Dependent variable: introduction of an innovation by a firm: $0=$ no innovation, $1=$ innovation 
The logistic regression model regarding the organizational-related activities (Table 8) of companies was highly significant (model Chisquare $=0.000$ ). Our model classifies observed observations into two groups extremely well. As a consequence, $75.8 \%$ of the total number of observations was correctly classified using a logistic regression model. The high classification rate of the model was based on a successful grouping of the other firms (companies without new organizational innovation, 84.6\%). In addition, the other group (innovators) was classified quite well.

The statistically significant variables were Internal, Size (1), and Size (2). A firm's know-how increases SMEs' opportunities to innovate when firms aggressively interact with their environment (see Cohen \& Levinthal, 1990; Lumpkin \& Dess, 2001: Beaver \& Prince, 2004). Moreover, stakeholders' utilization of management resources adds value to the firm's operations and increases the environmental management and innovativeness of the firm (see, e.g., Freeman et al., 2007; Harrison et al., 2010; Eesley \& Lenox, 2016) (H1 supported).

Table 8. The importance of stakeholders and firm-level characteristics related to organizational innovation in SMEs. Logistic regression model.

\begin{tabular}{llll}
\hline Explanatory variables & Coefficient & Standard error & Significance \\
\hline Internal & 0.935 & 0.255 & $0.000^{* * *}$ \\
Diffext & 0.011 & 0.285 & 0.970 \\
Pubsupp & 0.211 & 0.295 & 0.474 \\
Network & -0.116 & 0.323 & 0.718 \\
Size & & & $0.000^{* * *}$ \\
Size (1) & -2.961 & 0.431 & $0.000^{* * *}$ \\
Size (2) & -2.194 & 0.397 & $0.000^{* * *}$ \\
Industry & & & 0.538 \\
Industry (1) & -0.432 & 0.400 & 0.281 \\
Industry (2) & -0.551 & 0.801 & 0.492 \\
Constant & -0.787 & 0.974 & 0.419 \\
\hline
\end{tabular}

Notes: ${ }^{*}$ significant at $10 \%$; ${ }^{* *}$ significant at $5 \%$; ${ }^{* * *}$ significant at $1 \%$.

Partial classification rates (\%): firms with new organizational innovation $(\%)=63.7$; other firms $(\%)=84.6$ Model of Chi-square $=0.000 ; n=293 ; \mathrm{df}=8$, total classification rates $(\%)=75.8$

Dependent variable: introduction of an innovation by a firm: $0=$ no innovation, $1=$ innovation

In line with the results of the process innovation model and earlier studies (e.g., Van Dijk et al., 1997; Laforet, 2008), our results showed that organizational innovation was more focused in large (=over 20 employees) firms than in small (=less than 20 employees) firms ( $H 5$ supported). This result 
is partly in line with Bruhn et al. (2016), who found that firms with more than 70 employees in Brazil more frequently have organizational innovations. Furthermore, Abel-Koch et al. (2015) found that the share of firms that introduced organizational innovations in Germany was larger among firms with 50-249 employees than among firms with 10-49 employees.

\section{DISCUSSION}

It has been widely acknowledged that innovation in SMEs is far from an unequivocal phenomenon but rather is contingent on several factors. The aim of our study was to acquire knowledge of information sources (stakeholders) and characteristics of the company that potentially differentiate between the different types of innovation introduced in SMEs. In this study, innovative SMEs were compared to their noninnovative counterparts. By focusing on themes associated with the importance of internal capabilities, public support organizations, business network relations and various external information sources together with a firm's industry sector and size, the results at least partially tie well to the criteria made in previous studies. There were also unexpected findings that contradicted the existing evidence. Overall, the present study revealed a number of issues worthy of consideration by further research on SME innovation activities.

Our findings on product, process and marketing innovation showed that firms use various external sources of information in the innovation process (hypothesis 2). These various sources, such as fairs and educational meetings, may provide information that encourages firm innovativeness that is not otherwise available in the industry (see, e.g., Zahra, 1991; Shane, 2003; Freeman, et al., 2007; Harrison, et al., 2010). As Vaona and Pianta (2008, p. 283) noted, "product, process and marketing innovations are related to different innovative inputs and strategies pursued by firms." However, although a lack of strategic orientation may potentially emasculate the success of innovative endeavours in SMEs, from the results, it would also suggest that small firms striving for product, process and marketing innovations should adopt flexible strategies rather than ones that are "carved in stone." The present study confirmed the findings of Beaver and Prince's (2004) study, which argued that "the notion of strategic awareness as a specific capability and planning as an embedded process is much more critical than the written business plan for shaping the competitive posture of many small enterprises." However, these findings are somewhat contradictory to most studies in this area (see, e.g., Cohen \& Levinthal, 1990), as a firm's innovation process generally requires strong internal capabilities (hypothesis 1 ). 


\section{CONCLUSION}

Regarding the findings for marketing and organizational innovation, a positive relation was found between the internal capabilities of a firm and the creation of marketing and organizational innovation processes (hypothesis 1). These findings regarding SMEs' internal capabilities related to marketing and organizational innovation are consistent with research showing that innovation frequently needs special know-how by a firm's primary stakeholders (see, e.g., March, 1991; Eesley \& Lenox, 2006; Freeman et al., 2007). The utility of a firm's internal capabilities in innovation processes has also been found among Finnish SMEs (Saunila, 2016, 2020). As Cohen and Levinthal (1990) stated, the ease of learning and the uptake of technology are related to the extent to which innovation relates to the existing knowledge base. On the other hand, perhaps the most unexpected findings, which contradicted several older studies (see, e.g., Tödtling \& Kaufmann, 2001; Lechner \& Dowling, 2003; Tödtling et al., 2009), were that a firm's business network and use of public support organization were not related to the processes for the different types of innovation (hypothesis 3 and 4).

Considering the relation between innovation and the size of the firm, our results demonstrated that the introduction of a novel process and organizational innovation was associated with firm size, such that firms with more than 20 employees were concentrated in the group of innovators (hypothesis 5). This result is somewhat in line with most studies, which have found that innovativeness is stronger in larger firms, including Van Dijk et al. (1997), Laforet (2008), Damanpour (2010), Abel-Koch et al. (2015), and Bruhn et al. (2016). Furthermore, structuring the industry sector, competition and size can influence the creation of innovations. As Laforet $(2008$, p. 754) stated, "large firms in low-tech industries have an advantage over small firms, but no difference exists in high-tech industries."

Regarding our findings, it was found that the introduction of product innovation was connected to the firm's industry; therefore, firms in manufacturing and other industries were concentrated in the group of innovators, but KIBS firms were concentrated in the group of non-innovators (hypothesis 6). This result supported those of previous studies that indicated that innovation activity is more frequent in manufacturing firms than in services firms (e.g., see Beaudry \& Swann, 2009; Jiménez-Jiménez \& SanzValle, 2011; Segarra \& Teruel, 2014; Littunen \& Huovinen, 2020).

This study also provides suggestions for practice and policymakers. Our study found that public support organizations were not related to SME innovativeness (hypothesis 3). This finding is in line with Zeng et al. (2010), who found that suppliers, customers and other firms seem to be 
more important organizations in innovation processes than governments, universities, or research institutes. Furthermore, Saastamoinen et al. (2018) state that while developing new products for the public sector, SMEs should emphasize networks with other firms and place less emphasis on networks with public or private R\&D actors. In contrast, Huang et al. (2010) found that firms engaging in product innovations found universities and research institutions to be important information sources for innovation. However, our findings that public support organizations were not statistically significant in any innovation model are contrary to our expectations. Therefore, public support organizations should develop better mechanisms to find SMEs with strong motivations to develop new products and market opportunities. Thus, appropriate support mechanisms for innovative SMEs with growth endeavours would lower the threshold for taking the first critical steps, which are often characterized by the development of innovation and often the funding of innovation. Further, motivating entrepreneurs to interact with different stakeholders in innovation development is most important (Amara et al., 2016; Leiponen \& Helfat, 2010). Thus, a larger number of complementary knowledge sources may increase the probability of obtaining useful knowledge that leads to innovation. Our study found that firms using various types of external information sources, such as fairs, the media and the internet, increase SMEs' likelihood of creating product, process and marketing innovations (hypothesis 2).

Mole et al. (2017) state that SMEs may make suboptimal use of services and that because of imperfect information, they may have doubts about the value and reliability of the services, they may lack the time to wait for the benefits of services to accrue, there might be power imbalances or different world views between the owner and service advisers, and there might be uncertainty as to whether those advisers can be trusted or are fully aware of the needs of business managers. As a consequence, various relationships between firms and public support organizations increase trust and may lower the threshold of use of public services.

In regard to further research on the issues covered here, the primary stakeholders of SMEs related to the introduction of different types of innovations will be examined in more detail in other studies with a variety of data. Surprisingly, according to the findings of this study, networks with some primary stakeholders, such as customers, competitors and suppliers, were not linked to the introduction of different types of innovation.

Finally, it is appropriate to pay attention to some potential caveats regarding the study design and interpretations made on the grounds of empirical analysis. One could criticize the sample that includes firms from various industries, since, as argued by De Jong and Vermeulen (2006), it 
could diminish the value of the study regarding the implications for practice that could be made based on findings. Although it cannot be denied that differences do exist between industries with respect to their innovation practices (Pavitt, 1984), it has also been shown that small firms' innovation activities share many common features across both manufacturing and service sectors (see, e.g., Drejer, 2004; De Jong \& Marsili, 2006), suggesting that some general patterns of SME innovation do exist, although they are certainly not applicable to every firm in every industry. Furthermore, as De Jong and Vermuelen (2006) and Knoben (2009) noted, studies focusing on a single industry are also problematic, as the findings from these studies are difficult to generalize.

Moreover, the distinctive features of the country studied may have an impact on the research findings. Further studies in other countries are welcomed, and we encourage researchers in other countries to conduct a similar study for comparison in different countries. Although it is not easy to generalize the results of the study to other geographical contexts, we believe that parallel findings could be obtained when conducting the study in an economically and technologically advanced country. It is also important to remember that this study data were collected only from entrepreneurs and professionals. Because of their dominant position, entrepreneurs can be biased in their views of the business situation in their firms. Hence, somewhat different results might have been obtained if multiple informants had been used. Conversely, it is the opinions of entrepreneurs that are of interest because, after all, they are arguably the most important people in their respective firms in regard to strategy formulation and innovation orientation. However, our study has shed a little light on the subject for those interested in studying the innovativeness of SMEs, despite the potential limitations identified.

\section{Acknowledgment}

This study is a continuation of the study by Varis, M. \& Littunen, H. (EJIM, 2010, Vol 13 No. 2, pp. 128-154). In particular, we would like to thank Mr. Miika Varis for his valuable contributions in this area. We gratefully acknowledge funding from the Strategic Research Council (SRC) at the Academy of Finland for the project "Beyond MALPE-coordination: Integrative envisioning" (number 303552). The authors would also like to thank the Editors and the anonymous Reviewers for their useful comments. 


\section{References}

Abel-Koch, J., Del Bufalo, G., Fernandez, M., Gerstenberer, J., Lo, V., Navarro, B., \& Thornary, B. (2015). Investment and innovation. France, Germany, Italy and Spain. Retrieved from https://www.ico.es/documents/19/14629/ SME+Investment+and+Innovation+2015.pdf/1fa1ff45-66c6-4463-9ea061297e3ad630

Amara, N., D'Este, P., Landry, R., \& Doloreux, D. (2016). Impacts of obstacles on innovation patterns in KIBS firms. Journal of Business Research, 69(10), 4065-4073. http://dx.doi.org/10.1016/j.jbusres.2016.03.045.

Amara, N., \& Landry, R. (2005). Sources of information as determinants of novelty of innovation in manufacturing firms: Evidence from the 1999 statistics Canada innovation survey. Technovation, 25(3), 245-259. http://dx.doi.org/10.1016/S0166-4972(03)00113-5.

Antonelli, C., \& Scellato, G. (2015). Firms size and directed technological change. Small Business Economics, 44(1), 207-218. http://dx.doi. org/10.1007/s11187-014-9593-1.

Arvanitis, S. (1997). The impact of firm size on innovative activity - an empirical analysis based on Swiss firm data. Small Business Economics, 9(6), 473-490.

Asheim, B. T., Coenen, L., \& Svensson-Henning, M. (2003). Nordic SMEs Regional Innovation Systems: Final Report. Oslo: Nordic Innovation Center.

Audretsch, D. B. (2002). The dynamic role of small firms: Evidence from the US. Small Business Economics, 18(1-3), 13-40.

Barney, J. B. (1991). Firm resources and competitive advantage. Journal of Management, 17(1), 99-120.

Beaudry, C., \& Swann, G. M. P. (2009). Firm growth in industrial clusters of the United Kingdom. Small Business Economics, 32(4), 409-424. http:// dx.doi.org/10.1007/s11187-007-9083-9.

Beaver, G., \& Prince, C. (2004). Management, strategy and policy in the UK small business sector: A critical review. Journal of Small Business and Enterprise Development, 11(6), 34-49. http://dx.doi. org/10.1108/14626000410519083.

Becker, W., \& Dietz, J. (2004). R\&D cooperation and innovation activities of firms evidence for the German manufacturing industry. Research Policy, 33(2), 209-223. http://dx.doi.org/10.1016/j.respol.2003.07.003.

Belderbos, R., Gilsing, V. A., \& Suzuki, S. (2016). Direct and mediated ties to universities: "Scientific" absorptive capacity and innovation performance of pharmaceutical firms. Strategic Organization, 14(1), 32-52. http:// dx.doi.org/10.1177/1476127015604734.

Belderbos, R., Gilsing, V., Lokshin, B., Carree, M., \& Sastre, J. F. (2018). The antecedents of new R\&D collaborations with different partner types: On the dynamics of past R\&D collaboration and innovative 
performance. Long Range Planning, 51(2), 285-302. http://dx.doi. org/10.1016/j.Irp.2017.10.002.

Borrás, S., \& Edquist, C. (2013). The choice of innovation policy instruments. Technological Forecasting and Social Change, 80(8), 15131522. http://dx.doi.org/10.1016/j.techfore.2013.03.002.

Boter, H., \& Lundström, A. (2005). SME perspectives on business support services: The role of company size, industry and location. Journal of Small Business and Enterprise Development, 12(2), 244-258. http:// dx.doi.org/10.1108/14626000510594638.

Bridoux, F., \& Stoelhorst, J. W. (2014). Microfoundations for stakeholder theory: Managing stakeholders with heterogeneous motives. Strategic Management Journal, 35(1), 107-125. http://dx.doi.org/10.1002/ smj.2089.

Bruhn, N. C. P., Alcantara, J. N., \& Calegario, C. L. L. (2016). Multinational enterprises and spillover effects: A study on the factors associated with the innovation capacity of SMEs in Brazil. Revista ESPACIOS, 37(10), 1-12.

Cainelli, G., Evangelista, R., \& Savona, M. (2004). The impact of innovation on economic performance in services. The Service Industries Journal, 24(1), 116-130. http://dx.doi.org/10.1080/02642060412331301162.

Caloghirou, Y., Giotopoulos, I., Kontolaimou, A., Korra, E., \& Tsakanikas, A. (2021). Industry-university knowledge flows and product innovation: How do knowledge stocks and crisis matter?. Research Policy, 50(3), 104195.

Carroll, A. (1993). Business and Society, Business Ethics, and Stakeholder Management. Dallas: South-Western Publishing.

Carroll, A. (1995). Stakeholder thinking in three models of management morality: A perspective with strategic implications. In J. Näsi (Ed.), Understanding Stakeholder Thinking (pp. 44-47). Jyväskylä, Finland: LSR Publications.

Carvalho, L., Costa, T., \& Caiado, J. (2013). Determinants of innovation in a small open economy: A multidimensional perspective. Journal of Business Economics and Management, 14(3), 583-600. http://dx.doi.or $\mathrm{g} / 10.3846 / 16111699.2012 .701225$.

Cassiman, B., \& Veugelers, R. (2006). In search of complementarity in innovation strategy: Internal R\&D and external knowledge acquisition. Management Science, 52(1), 68-82. http://dx.doi.org/10.1287/mnsc.1050.0470.

Cassiman, B., Di Guardo, M. C., \& Valentini, G. (2009). Organizing R\&D projects to profit from innovation: Insights from co-opetition. Long Range Planning, 42(2), 216-233.

Chang, Y. Y., Hughes, M., \& Hotho, S. (2011). Internal and external antecedents of SMEs' innovation ambidexterity outcomes. Management Decision, 49(10), 1658-1676. http://dx.doi.org/10.1108/00251741111183816.

Cohen, W. M., \& Levinthal, D. A. (1990). Absorptive capacity: A new perspective on learning and innovation. Administrative Science Quarterly, 35(1), 128152. http://dx.doi.org/10.2307/2393553. 
Cravo, T. A., \& Piza, C. (2019). The impact of business-support services on firm performance: A meta-analysis. Small Business Economics, 53(3), 753-770. http://dx.doi.org/10.1007/s11187-018-0065-x.

Cronbach, L. J. (1951). Coefficient alpha and the internal structure of tests. Psychometrika 16(3), 297-334. http://dx.doi.org/10.1007/BF02310555.

Damanpour, D. (2010). An integration of research findings of effects of firm size and market competition on product and process innovations. British Journal of Management, 21(4), 996-1010. http://dx.doi.org/10.1111/ j.1467-8551.2009.00628.x.

De Jong, J. P. J., \& Marsili, O. (2006). The fruit flies of innovations: A taxonomy of innovative small firms. Research Policy, 35(2), 213-229. http://dx.doi. org/10.1016/j.respol.2005.09.007.

De Jong, J. P .J., \& Vermeulen, P. A. M. (2006). Determinants of product innovation in small firms: A comparison across industries. International Small Business Journal, 24(6), 587-609. http://dx.doi. org/10.1177/0266242606069268.

Demirel, P., \& Mazzucato, M. (2012). Innovation and firm growth: Is R \& D worth it?. Industry and Innovation, 19(1), 45-62. http://dx.doi.org/10.10 80/13662716.2012.649057.

Deschryvere, M. (2014). R\&D, firm growth and the role of innovation persistence: An analysis of Finnish SMEs and large firms. Small Business Economics, 43(4), pp.767-785. http://dx.doi.org/10.1007/s11187-0149559-3.

Dickson, P. H., Weaver, K. M., \& Hoy, F. (2006). Opportunism in the R\&D alliances of SMES: The roles of the institutional environment and SME size. Journal of Business Venturing, 21(4), 487-513. http://dx.doi. org/10.1016/j.jbusvent.2005.02.003.

Doloreux, D. (2004). Regional networks of small and medium sized enterprises: Evidence from the metropolitan area of Ottawa in Canada. European Planning Studies, 12(2), 173-189. http://dx.doi.org/10.1080/09654310 42000183923.

Drejer, I. (2004). Identifying innovation in surveys of services: A Schumpeterian perspective. Research Policy, 33(3), 551-562. http:// dx.doi.org/10.1016/j.respol.2003.07.004.

Eesley, C., \& Lenox, M. J. (2006). Firm responses to secondary stakeholder action. Strategic Management Journal, 27(8), 765-781. http://dx.doi. org/10.1002/smj.536.

European Union. (2020). The revised user guide to the SME definition. SME definition I Internal Market, Industry, Entrepreneurship and SMEs. Retrieved from https://ec.europa.eu/growth/smes/sme-definition_en

Freel, M. (2003). Sectoral patterns of small firm innovation, networking and proximity. Research Policy, 32(5), 751-770. http://dx.doi.org/10.1016/ S0048-7333(02)00084-7.

Freel, M. S., \& Robson, P. J. A. (2004). Small firm innovation, growth and performance. International Small Business Journal, 22(6), 561-575. 
Freel, M., \& De Jong, J. P. (2009). Market novelty, competence-seeking and innovation networking. Technovation, 29(12), 873-884. http://dx.doi. org/10.1016/j.technovation.2009.07.005.

Freeman, R. E. (1984). Strategic Management- A Stakeholder Approach. Boston: Pitman.

Freeman R. E., Harrison J. S., \& Wicks A. C. (2007). Managing for Stakeholders: Survival, Reputation and Success. New Haven, CT: Yale University Press.

Ghosh, B. C., Liang, T. W., Meng, T. T., \& Chan, B. (2001). The key success factors, distinctive capabilities and strategic thrusts of top SMEs in Singapore. Journal of Business Research, 51(3), 209-221. http://dx.doi. org/10.1016/S0148-2963(99)00047-8.

Grama-Vigouroux, S., Saidi, S., Berthinier-Poncet, A., Vanhaverbeke, W., \& Madanamoothoo, A. (2020). From closed to open: A comparative stakeholder approach for developing open innovation activities in SMEs. Journal of Business Research, 119, 230-244. http://dx.doi. org/10.1016/j.jbusres.2019.08.016.

Hagedoorn, J. (1996). Innovation and entrepreneurship: Schumpeter revisited. Industrial and Corporate Change, 5(3), 883-896. http://dx.doi. org/10.1093/icc/5.3.883.

Hagedoorn, J. (2002). Inter-firm R\&D partnerships: An overview of major trends and patterns since 1960. Research Policy, 31(4), 477-492. http:// dx.doi.org/10.1016/S0048-7333(01)00120-2.

Harrison, J. S., Bosse, D. A., \& Phillips, R. A. (2010). Managing for stakeholders, stakeholder utility functions, and competitive advantage. Strategic Management Journal, 31(1), 58-74. http://dx.doi.org/10.1002/smj.801.

Henrekson, M., \& Johansson, D. (2010). Gazelles as job creators: A survey and interpretation of the evidence. Small Business Economics, 35(2), 227-244. http://dx.doi.org/10.1007/s11187-009-9172-z.

Hervas-Oliver, J. L., Garrigos, J. A., \& Gil-Pechuan, I. (2011). Making sense of innovation by $R \& D$ and non-R\&D innovators in low technology contexts: A forgotten lesson for policymakers. Technovation, 31(9), 427-446. http://dx.doi.org/10.1016/j.technovation.2011.06.006.

Hervas-Oliver, J. L., Boronat-Moll, C., \& Sempere-Ripoll, F. (2016). On process innovation capabilities in SMEs: A taxonomy of process-oriented innovative SMEs. Journal of Small Business Management, 54, 113-134. http://dx.doi.org/10.1111/jsbm.12293.

Hosmer, D. W., \& Lemeshow, S. (2000). Applied Logistic Regression, 2nd edition. New York: Wiley.

Hossain, M., \& Kauranen, I. (2016). Open innovation in SMEs: A systematic literature review. Journal of Strategy and Management, 9(1), 58-73. http://dx.doi.org/10.1108/JSMA-08-2014-0072.

Howells, J. (2005). Innovation and regional economic development: A matter of perspective?. Research Policy, 34(8), 1220-1234. http://dx.doi. org/10.1016/j.respol.2005.03.014. 
Howells, J., \& Roberts, J. (2000). From innovation systems to knowledge systems. Prometheus: Critical Studies in Innovation, 18(1), 17-31. http:// dx.doi.org/10.1080/08109020050000636.

Huang, C., Arundel, A., \& Hollanders, H. (2010). How firms innovate: R\&D, non-R\&D, and technology adoption. Retrieved from http://collections. unu.edu/view/UNU:405\#viewAttachments

Ilori, A. B., Lawal, A., \& Simeon-Oke, O. O. (2017). Innovations and innovation capability in palm kernel processing industry in southwestern Nigeria. International Journal of Innovation Science, 9(1), 102-114. http://dx.doi.org/10.1108/IJIS-10-2016-0045.

Ipinnaiye, O., Dineen, D., \& Lenihan, H. (2017). Drivers of SME performance: A holistic and multivariate approach. Small Business Economics, 48(4), 883-911. http://dx.doi.org/10.1007/s11187-016-9819-5.

Jiménez-Jiménez, D., \& Sanz-Valle, R. (2011). Innovation, organizational learning, and performance. Journal of Business Research, 64(4), 408417. http://dx.doi.org/10.1016/j.jbusres.2010.09.010.

Jones T. M., \& Wicks A. C. (1999). Convergent stakeholder theory. Academy of Management Review, 24(2), 206-221. http://dx.doi.org/10.5465/ amr.1999.1893929.

Jones, T. M., Harrison, J. S., \& Felps, W. (2018). How applying instrumental stakeholder theory can provide sustainable competitive advantage. Academy of Management Review, 43(3), 371-391. http:// dx.doi.org/10.5465/amr.2016.0111.

Jones-Evans, D., Gkikas, A., Rhisiart, M., \& MacKenzie, N. G. (2018). Measuring open innovation in SMEs. In F.F. W. Vanhaverbeake, F. Frattini, N. Roijakkers, M. Usman (Eds.), Researching Open Innovation in SMEs (pp. 399-427). New Jersey: https://doi.org/10.1142/9789813230972_0013

Kafetzopoulos, D., \& Psomas, E. (2015). The impact of innovation capability on the performance of manufacturing companies: The Greek case. Journal of Manufacturing Technology Management, 26(1), 104-130. http:// dx.doi.org/10.1108/JMTM-12-2012-0117.

Kang, K., \& Park, H. (2012). Influence of government R\&D support and inter-firm collaborations on innovation in Korea biotechnology SMEs. Technovation, 32(1), 400-414.

Kaufmann, A., \& Tödtling, F. (2002). How effective is innovation support for SMEs? An analysis of the region of Upper Austria. Technovation, 22(3), 147-159. http://dx.doi.org/10.1016/S0166-4972(00)00081-X.

Keskin, H. (2006). Market orientation, learning orientation, and innovation capabilities in SMEs: An extended model. European Journal of Innovation Management, 9(4), 396-417. http://dx.doi. org/10.1108/14601060610707849.

Khairuddin, S., Qureshi, Z. H., Wahid, R. A., Tehseen, S., Pathan, Z. H., \& Khan, M. R. K. (2019). A conceptual study on contingent impact of external integration on innovation SME business success relationship. International 
Journal of Financial Research, 10(5), 370. http://dx.doi.org/10.5430/ijfr. v10n5p370.

Kirchhoff, B. A., Linton, J. D., \& Walsh, S. T. (2013). Neo-Marshellian equilibrium versus Scumpeterian creative destruction: Its impact on Business research and economic policy. Journal of Small Business Management, 51(2), 159-166.

Knoben, J. (2009). Localized inter-organizational linkages, agglomeration effects, and the innovative performance of firms. The Annals of Regional Science, 43(30), 757-779. http://dx.doi.org/10.1007/s00168-008-02298.

Kreiser, P. M., Marino, L. D., \& Weaver, K.M. (2002). Assessing the psychometric properties of the entrepreneurial orientation scale: A Multi-Country Analysis. Entrepreneurship Theory and Practice, 26(4), 71-94. http:// dx.doi.org/10.1177/104225870202600405.

Laforet, S. (2008). Size, strategic, and market orientation affects on innovation. Journal of Business Research, 61(7), 753-764. http://dx.doi. org/10.1016/j.jbusres.2007.08.002.

Landoni, P., Dell'Era, C., Ferraloro, G., Peradotto, M., Karlsson, H., \& Verganti, R. (2016). Design contribution to the competitive performance of SMEs: The role of design innovation capabilities. Creativity and Innovation Management, 25(4), 484-499. http://dx.doi.org/10.1111/caim.12165.

Lecerf, M., \& Omrani, N. (2020). SME internationalization: The impact of information technology and innovation. Journal of the Knowledge Economy, 11(2), 805-824. http://dx.doi.org/10.1007/s13132-018-05763.

Lechner, C., \& Dowling, M. (2003). Firm networks: external relationships as sources for the growth and competitiveness of entrepreneurial firms. Entrepreneurship \& Regional Development, 15(1), 1-26. http://dx.doi. org/10.1080/08985620210159220.

Leiponen, A. (2005). Organization of knowledge and innovation: the case of Finnish business services. Industry and Innovation, 12(2), 185-203. http://dx.doi.org/10.1080/13662710500087925.

Leiponen, A. (2012). The benefits of R\&D and breadth in innovation strategies: A comparison of Finnish service and manufacturing firms. Industrial and Corporate Change, 21(5), 1255-1281. http://dx.doi.org/10.1093/icc/ dts022.

Leiponen, A., \& Helfat, C. E. (2010). Innovation objectives, knowledge sources, and the benefits of breadth. Strategic Management Journal, 31(2), 224236. http://dx.doi.org/10.1002/smj.807.

Leonidou, E., Christofi, M., Vrontis, D., \& Thrassou, A. (2020). An integrative framework of stakeholder engagement for innovation management and entrepreneurship development. Journal of Business Research, 119, 245258. http://dx.doi.org/10.1016/j.jbusres.2018.11.054.

Littunen, H., \& Huovinen, J. (2020). Innovation and performance among firms in Finland: The impact of firm-level characteristics. International Journal 
of Innovation and Regional Development, 9(2), 102-120. http://dx.doi. org/10.1504/IJIRD.2020.110505.

Littunen, H., \& Rissanen, S. (2015). Information sources and innovation linked networking: Relations to health and social service enterprises' performance in Finland. Innovation and Development, 5(1), 93-111, http://dx.doi.org/10.1080/2157930X.2014.994261.

Llerena, P., \& Oltra, V. (2002). Diversity of innovative strategy as a source of technological performance. Structural Change and Economic Dynamics, 13(2), 179-201. http://dx.doi.org/10.1016/S0954-349x(01)00036-4.

Lukovszki, L., Rideg, A., \& Sipos, N. (2020). Resource-based view of innovation activity in SMEs: An empirical analysis based on the global competitiveness project. Competitiveness Review: An International Business Journal, 31(3), 513-541. http://dx.doi.org/10.1108/CR-01-2020-0018.

Lumpkin, G. T., \& Dess, G. G. (2001). Linking two dimensions of entrepreneurial orientation to firm performance: The moderating role of environment and industry life cycle. Journal of Business Venturing, 16(5), 429-451.

Lööf, H., \& Heshmati, A. (2006). On the relationship between innovation and performance: A sensitivity analysis. Economics of Innovation and New Technology, 15(4-5), 317-344. http://dx.doi. org/10.1080/10438590500512810.

Maldonado-Guzmán, G., Garza-Reyes, J. A., Pinzón-Castro, S. Y., \& Kumar, V. (2019). Innovation capabilities and performance: Are they truly linked in SMEs?. International Journal of Innovation Science, 11(1), 1757-2223. http://dx.doi.org/10.1108/IJIS-12-2017-0139.

Malerba, F. (1992). Learning by firms and incremental technical change. The Economic Journal, 102(413), 845-859. http://dx.doi. org $/ 10.2307 / 2234581$.

Mansury, M. A., \& Love, J. H. (2008). Innovation, productivity and growth in US business services: A firm-level analysis. Technovation, 28(1-2), 5262. http://dx.doi.org/10.1016/j.technovation.2007.06.002.

March J.G. (1991). Exploration and exploitation in organizational learning. Organization Science, 2(1), 71-87. http://dx.doi.org/10.1287/ orsc.2.1.71.

De Martino, M., \& Magnotti, F. (2018). The innovation capacity of small food firms in Italy. European Journal of Innovation Management. 21(3), 362383. http://dx.doi.org/10.1108/EJIM-04-2017-0041.

Mejia, A., \& Arias-Perez, J. (2017). Approach to differences in product and process innovation capabilities and financial performance in manufacturing companies. Revista ESPACIOS, 38(04). https://www. revistaespacios.com/a17v38n04/17380412.html

Miles, I., Kastrinos, N., Flanagan, K., Bilderbeek, R., Den Hertog, P., Huntink, W., \& Bouman, M. (1995). Knowledge-intensive business services: Their role as users, carriers and sources of innovation. Retrieved from https:// www.research.manchester.ac.uk/portal/files/32800224/FULL_TEXT.PDF 
Mole, K., North, D., \& Baldock, R. (2017). Which SMEs seek external support? Business characteristics, management behaviour and external influences in a contingency approach. Environment and Planning C: Politics and Space, 35(3), 476-499. http://dx.doi.org/10.1177/0263774X16665362.

Muller, E., \& Zenker, A. (2001). Business services as actors of knowledge transformation: The role of KIBS in regional and national innovation systems. Research Policy, 30(9), 1501-1516. http://dx.doi.org/10.1016/ S0048-7333(01)00164-0.

Negassi, S., Lhuillery, S., Sattin, J. F., Hung, T. Y.,, \& Pratlong, F. (2019). Does the relationship between innovation and competition vary across industries? Comparison of public and private research enterprises. Economics of Innovation and New Technology, 28(5), 465-482. http://dx.doi.org/10.1 080/10438599.2018.1527552.

Nieto, M. J., \& Santamaría, L. (2007). The importance of diverse collaborative networks for the novelty of product innovation. Technovation, 27(6-7), 367-377. http://dx.doi.org/10.1016/j.technovation.2006.10.001.

Nunally, J. (1978). Psychometric Theory. New York. NY: McGraw-Hill.

O'Cass, A., \& Sok, P. (2014). The role of intellectual resources, product innovation capability, reputational resources and marketing capability combinations in firm growth. International Small Business Journal, 32(8), 996-1018. http://dx.doi.org/10.1177/0266242613480225.

OECD. (1997). Oslo Manual: Proposed Guidelines for Collecting and Interpreting Technological Innovation Data. $2^{\text {nd }}$ edition. Paris: OECD.

OECD. (2005). The Measurement of Scientific and Technological Activities: Guidelines for Collecting and Interpreting Innovation Data, Oslo Manual, 3rd ed. Paris: OECD.

OECD/Eurostat. (2018). The measurement of scientific, technological and innovation activities: Guidelines for collecting, reporting and using data for innovation, Oslo Manual 2018, 4th ed. Paris/Eurostat, Luxembourg: OECD Publishing. https://doi.org/10.1787/9789264304604-en.

Official Statistics of Finland (OSF). (2020). Innovaatiotoiminta 2018. Innovation. Helsinki: Statistics Finland. Tiede, teknologia ja tietoyhteiskunta 2020. Part of Eurostat Community Innovation Survey (CIS). Retrieved from http://www.stat.fi/til/inn/index_en.html.

Official Statistics of Finland (OSF). (2021). Structural business and financial statement statistics. Helsinki: Statistics Finland. Retrieved from http:// www.stat.fi/til/yrti/meta_en.html.

Olmos-Peñuela, J., García-Granero, A., Castro-Martínez, E., \& D’Este, P. (2017). Strengthening SMEs' innovation culture through collaborations with public research organizations. Do all firms benefit equally?. European Planning Studies, 25(11), 2001-2020. http://dx.doi.org/10.1080/096543 13.2017.1279592.

Park, Y., Shin, J., \& Kim, T. (2010). Firm size, age, industrial networking, and growth: A case of the Korean manufacturing industry. Small Business 
Economics, 35(2), 153-168. http://dx.doi.org/10.1007/s11187-0099177-7.

Pavitt, K. (1984). Sectoral patterns of technical change: Towards a taxonomy and a theory. Research Policy, 13(6), 343-373. http://dx.doi. org/10.1016/0048-7333(84)90018-0

Peeters, C., \& van Pottelsberghe de la Potterie, B. (2006). Innovation strategy and the patenting behaviour of firms. Journal of Evolutionary Economics, 16(1-2), 109-135.

Penrose, E. (1959). The Theory of the Growth of the Firm. New York, NY: John Wiley.

Petrou, A., \& Daskalopoulou (2013). Social capital and innovation in service sector. European Journal of Innovation Management, 16(1), 50-69. http://dx.doi.org/10.1108/14601061311292850.

Phillips R. A. (2003). Stakeholder Theory and Organizational Ethics. San Francisco, CA.: Berrett-Koehler.

Pollack, J. M., Barr, S., \& Hanson, S. (2017). New venture creation as establishing stakeholder relationships: A trust-based perspective. Journal of Business Venturing Insights, 7, 15-20. http://dx.doi.org/10.1016/j. jbvi.2016.12.003.

Prahalad, C. K., \& Hamel, G. (1990). The core competence of the corporation. Harvard Business Review, 68(May-June), 79-91.

Prajogo, D. I. (2006). The relationship between innovation and business performance-a comparative study between manufacturing and service firms. Knowledge and Process Management, special issue: Continuous Innovation, Performance and Knowledge Management, 13(3), 218-225. http://dx.doi.org/10.1002/kpm.259.

Rigtering, J. C., Kraus, S., Eggers, F., \& Jensen, S. H. (2014). A comparative analysis of the entrepreneurial orientation/growth relationship in service firms and manufacturing firms. The Service Industries Journal, 34(4), 275294. http://dx.doi.org/10.1080/02642069.2013.778978.

Rodriguez, M., Doloreux, D. \& Shearmur, R. (2017). Variety in external knowledge sourcing and innovation novelty: Evidence from the KIBS sector in Spain. Technovation, 68(December), 35-43. http://dx.doi. org/10.1016/j.technovation.2017.06.003.

Rogers, M. (2004). Networks, firm size and innovation. Small Business Economics, 22(2), 141-153. http://dx.doi.org/10.1023/ B:SBEJ.0000014451.99047.69.

Rosenzweig, S. (2017). The effects of diversified technology and country knowledge on the impact of technological innovation. The Journal of Technology Transfer, 42(3), 564-584. http://dx.doi.org/10.1007/s10961016-9492-5.

Saastamoinen, J., Reijonen, H., \& Tammi, T. (2018). Should SMEs pursue public procurement to improve innovative performance?. Technovation, 69, 2-14. http://dx.doi.org/10.1016/j.technovation.2017.10.003. 
Santoro, G., Vrontis, D., Thrassou, A., \& Dezi, L. (2018). The Internet of Things: Building a knowledge management system for open innovation and knowledge management capacity. Technological Forecasting and Social Change, 136, 347-354. http://dx.doi.org/10.1016/j. techfore.2017.02.034.

Saunila, M. (2016). Performance measurement approach for innovation capability in SMEs. International Journal of Productivity and Performance Management, 65(2), 162-176. http://dx.doi.org/10.1108/ IJPPM-08-2014-0123.

Saunila, M. (2020). Innovation capability in SMEs: A systematic review of the literature. Journal of Innovation \& Knowledge, 5(4), 260-265. http:// dx.doi.org/10.1016/j.jik.2019.11.002.

Sawang, S., \& Unsworth, K. (2011). Why adopt now? Multiple case studies and survey studies comparing small, medium and large firms. Technovation, 31(10), 554-559. http://dx.doi.org/10.1016/j.technovation.2011.06.002.

Schumpeter. J.A. (1939) Business Cycles. Philagdelphia: Porcupine Press.

Segarra, A,. \& Teruel, M. (2014). High-growth firms and innovation: An empirical analysis for Spanish firms. Small Business Economics, 43(4), 805-821. http://dx.doi.org/10.1007/s11187-014-9563-7.

Shane, S. (2003). A General Theory of Entrepreneurship, the IndividualOpportunity Nexus. Massachusetts: Edward Elgar Publishing, Inc.

Shearmur, R., \& Doloreux, D. (2019). KIBS as both innovators and knowledge intermediaries in the innovation process: Intermediation as a contingent role. Papers in Regional Science, 98(December), 191-209. http://dx.doi. org/10.1111/pirs.12354.

Statistics Finland. (2014). Structural Business and Financial Statement Statistics. Helsinki. Retrieved from https://www.stat.fi/til/yrti/tup_ en.html

Storey, D. (1994). Understanding the Small Business Sector. London: Routledge.

Tang, Z., \& Tang, J. (2012). Stakeholder-firm power difference, stakeholders' CSR orientation, and SMEs' environmental performance in China. Journal of Business Venturing, 27(4), 436-455. http://dx.doi.org/10.1016/j. jbusvent.2011.11.007.

Tang, J., Tang, Z., Marino, L. D., Zhang, Y., \& Li Q. (2008). Exploring an inverted $\mathrm{u}$-shape relationship between entrepreneurial orientation and performance in Chinese Ventures. Entrepreneurship Theory and Practice, 32(1), 219-239. http://dx.doi.org/10.1111/j.1540-6520.2007.00223.x.

Tansey, R., White, M., Long, R. G., \& Smith, M. (1996). A comparison of loglinear modeling and logistic regression in management research. Journal of Management, 22(2), 339-358. http://dx.doi. org/10.1177/014920639602200207.

Tavakol, M., \& Dennick, R. (2011). Making sense of Cronbach's alpha. International Journal of Medical Education, 2, 53-55. http:// dx.doi.org/10.5116/ijme.4dfb.8dfd. 
Tether, B. S. (2002). Who co-operates for innovation, and why: An empirical analysis. Research Policy, 31(6), 947-967.

Tether, B. S. (2005). Do services innovate (differently)? Insights from the European Innobarometer Survey. Industry and Innovation, 12(2), 153184. http://dx.doi.org/10.1080/13662710500087891.

Trott, P. (2002). Innovation Management and New Product Development, 2nd ed. Essex: Pearson Education.

Tödtling, F., \& Kaufmann, A. (2001). The role of the region for innovation activities of SMEs. European Urban and Regional Studies, 8(3), 203-15. http://dx.doi.org/10.1177/096977640100800303.

Tödtling, F., Lehner, P., \& Kaufmann, A. (2009). Do different types of innovation rely on specific kinds of knowledge interactions?. Technovation, 29(1), 59-71. http://dx.doi.org/10.1016/j.technovation.2008.05.002.

Van Dijk, B., Hertog, R., Menkveld, B., \& Thurik, R. (1997). Some new evidence on the determinants of large and small-firm innovation. Small Business Economics, 9(4), 335-343.

Vaona, A., \& Pianta, M. (2008). Firm size and innovation in European manufacturing. Small Business Economics, 30(3), 283-299. http://dx.doi. org/10.1007/s11187-006-9043-9.

Varis, M., \& Littunen H. (2010). Types of innovation, sources of information and performance in entrepreneurial SMEs. European Journal of Innovation Management, 13(2), 128-154. http://dx.doi. org/10.1108/14601061011040221.

Vedung, E. (1998). Policy instruments: typologies and theories. In M.L. Bemelmans-Videc, R.C. Rist, \& E. Vedung (Eds.), Carrots, Sticks, and Sermons: Policy Instruments and Their Evaluation (pp. 21-58). London: Routledge.

Vega-Jurado, J., Gutiérrez-Gracia A., Fernández-de-Lucio, I., \& ManjarrésHenríquez, L. (2008). The effect of external and internal factors on firms' product innovation. Research Policy, 37(4), 616-632. http://dx.doi. org/10.1016/j.respol.2008.01.001.

Vos, J-P. (2005). Developing strategic self-descriptions of SMEs. Technovation, 25(9), 989-999. http://dx.doi.org/10.1016/j.technovation.2004.02.014.

Voudouris, I., Lioukas, S., latrelli, M., \& Caloghirou, Y. (2012). Effectiveness of technology investment: Impact of internal technological capability, networking and investment's strategic importance. Technovation, 32(6), 400-414. http://dx.doi.org/10.1016/j.technovation.2012.04.001.

Vrontis, D., Thrassou, A., Santoro, G., \& Papa, A. (2017). Ambidexterity, external knowledge and performance in knowledge-intensive firms. The Journal of Technology Transfer, 42(2), 374-388. http://dx.doi.org/10.1007/ s10961-016-9502-7.

Walsh, S. T., \& Linton, J. D. (2001). The competence pyramid: A framework for identifying and analysing firm and industry competence. Technology Analysis \& Strategic Management, 13(2), 165-177. http://dx.doi. org/10.1080/09537320124246. 
Weerawardena, J., O'Cass, A., \& Julian, C. (2006). Does industry matter? Examining the role of industry structure and organizational learning in innovation and brand performance. Journal of Business Research, 59(1), 37-45. http://dx.doi.org/10.1016/j.jbusres.2005.02.004.

Wong, P. K., Ho, T.P., \& Autio, E. (2005). Entrepreneurship, innovation and economic growth: Evidence from GEM data. Small Business Economics, 24(3), 335-350. http://dx.doi.org/10.1007/s11187-005-2000-1.

Woschke, T. \& Haase, H., \& Kratzer, J. (2017). Resource scarcity in SMEs: Effects on incremental and radical innovations. Management Research Review, 40(2), 195-217. http://dx.doi.org/10.1108/MRR-10-2015-0239.

Zahra, S. A. (1991). Predictors and financial outcomes of corporate entrepreneurship: An exploratory study. Journal of Business Venturing, 6(4), 259-285. http://dx.doi.org/10.1016/0883-9026(91)90019-A.

Zahra, S. A., \& Covin, J. G., (1993). Business strategy, technology policy and firm performance. Strategic Management Journal, 14(6), 451-478. http://dx.doi.org/10.1002/smj.4250140605.

Zeng, S. X., Xie, X. M., \& Tam, C. M. (2010). Relationship between cooperation networks and innovation performance of SMEs. Technovation, 30(3), 181-194. http://dx.doi.org/10.1016/j.technovation.2009.08.003.

\section{Appendices}

Appendix 1. KIBS sector includes

- Computer and related activities

- Research and development

- Legal, accounting, book-keeping and auditing activities; tax consultancy; debt collecting

- Market research and public opinion polling; advertising; trade fair and product demonstration activities

- Architectural and engineering activities and related technical consultancy; technical testing and analysis; industrial design

- Business and management consultancy activities; labour recruitment and provision of personnel

Appendix 2. Correlations

\begin{tabular}{llllllll}
\hline & Internal & Diffext & Pubsupp & Network & Size & Product Process Marketing \\
Internal & 1 & & & & & & \\
Diffext & $0.521^{* *}$ & 1 & & & & \\
Pubsupp & $0.426^{* *}$ & $0.562^{* *}$ & 1 & & & \\
Network & $0.492^{* *}$ & $0.572^{* *}$ & $0.516^{* *}$ & 1 & & \\
Size & $0.371^{* *}$ & $0.220^{* *}$ & $0.330^{* *}$ & $0.224^{* *}$ & 1 & & \\
Product & $0.214^{* *}$ & $0.277^{* *}$ & $0.153^{* *}$ & $0.159^{* *}$ & $0.189^{* *}$ & 1 & \\
& & & & & & & \\
\end{tabular}




\begin{tabular}{lllllllll}
\hline & Internal & Diffext & Pubsupp & Network & Size & Product & Process & Marketing \\
\hline Process & $0.228^{* *}$ & $0.285^{* *}$ & $0.221^{* *}$ & $0.177^{* *}$ & $0.254^{* *}$ & $0.425^{* *}$ & 1 & \\
Marketing & $0.243^{* *}$ & $0.283^{* *}$ & $0.209^{* *}$ & $0.208^{* *}$ & $0.178^{* *}$ & $0.337^{* *}$ & $0.154^{* *}$ & 1 \\
Organizational & $0.369^{* *}$ & $0.250^{* *}$ & $0.283^{* *}$ & $0.200^{* *}$ & $0.550^{* *}$ & $0.251^{* *}$ & $0.272^{* *}$ & $0.336^{* *}$
\end{tabular}

Note: Correlation is significant at the 0.01 level (2-tailed). ${ }_{* *}$ Correlation is significant at the 0.05 level (2-tailed).

\begin{abstract}
Abstrakt
CEL: Celem artykułu jest analiza znaczenia zarówno wewnętrznych zdolności (zasobów), jak i zewnętrznych źródeł informacji we wdrażaniu innowacji produktowych, procesowych, marketingowych i organizacyjnych majqcych na celu maksymalizację przewagi konkurencyjnej firmy oraz tworzenie wartości dla interesariuszy. Ponadto w szczególności badamy rolę organizacji publicznych, sieci biznesowych, wielkości firmy i sektora przemysłu w pojawianiu się różnego rodzaju innowacji produktowych, procesowych, marketingowych i organizacyjnych. Badania oparto na typologii innowacji (produktowej, procesowej, marketingowej i organizacyjnej) przyjętej przez OECD. METODYKA: Artykuł opiera się na danych z 389 MŚP zlokalizowanych w Finlandii i opisuje opracowanie modelu do testowania czynników zwiększajq̨cych innowacyjność MŚP. Jako metodologię zastosowano model regresji logistycznej. WYNIKI: Wyniki pokazujq, że tworzenie nowych produktów, procesów i innowacji marketingowych jest powiq̨zane z różnymi zewnętrznymi źródłami informacji, takimi jak targi, media i internet. Ponadto zwiq̨zek między wewnętrznymi zdolnościami, takimi jak know-how firmy, zwiększa innowacyjność marketingowq i organizacyjnq MŚP. Nasze wyniki wykazały, że tworzenie innowacji produktowych jest pozytywnie powiqzane $z$ produkcjq. Ponadto stwierdzamy, że tworzenie nowych procesów i innowacji organizacyjnych jest zwiqzane z wielkościq firmy, tak iż firmy zatrudniajqce mniej niż 20 pracowników (firmy najmniejsze) były skoncentrowane wśród nieinnowatorów, a firmy zatrudniajqce więcej niż 20 pracowników były skoncentrowane wśród innowatorów. IMPLIKACJE DLA TEORII I PRAKTYKI: Wkładem naszego badania jest przeanalizowanie, w jakim stopniu różne rodzaje innowacji opierajq się na konkretnych źródłach informacji. Niniejsze badanie zawiera również sugestie dla praktyków i decydentów. Wbrew oczekiwaniom dotyczqcym naszych wyników organizacje wsparcia publicznego nie były statystycznie istotne w żadnym modelu innowacji. Dlatego organizacje wsparcia publicznego powinny opracować lepsze mechanizmy znajdowania MŚP z silnq motywacja do opracowywania nowych produktów i możliwości rynkowych. ORYGINALNOŚĆ I WARTOŚĆ: Ten artykuł przedstawia nowy i aktualny punkt widzenia dla literatury, badając możliwe czynniki wyjaśniajqce wzrost prawdopodobieństwa wdrożenia przez MŚP innowacji produktowych, procesowych, marketingowych i organizacyjnych. Nasze badanie dostarcza wyczerpujq̨cych informacji na temat tego, w jaki sposób różni interesariusze przyczyniajq się do powstawania innowacji w MŚP. Słowa kluczowe: MŚP, innowacyjność, możliwości wewnętrzne, zewnętrzne źródła informacji, interesariusze, sektor przemysłu, wielkość firmy
\end{abstract}




\section{Biographical notes}

Hannu Littunen, Ph.D., is an Emeritus Professor of entrepreneurship and regional development. After graduating from the University of Jyväskylä, he has been a Researcher at the University of Jyväskylä, School of Business and Economics, Centre for Economic Research, Finland (1981-2002), and a Professor of entrepreneurship and regional development at the University of Eastern Finland (2003-2015). Research conducted by Hannu Littunen has mainly focused on factors relating to new firms' innovation and success, entrepreneurship and regional development. He has published in journals such as European Journal of Innovation Management, Innovation and Development, International Journal of Entrepreneurial Behaviour and Research, Small Business Economics, Entrepreneurship and Regional Development, Family Business Review and others.

Timo Tohmo, Ph.D., is a Senior Researcher in Economics at the Jyväskylä University School of Business and Economics, JSBE, Finland. His research includes factors relating to firms' innovation and success, regional economics, cultural economics, tourism economics, and economic impact studies. He has also been interested in the intersectoral mobility of Finnish academics.

Esa Storhammar, Ph.D., is a Senior Researcher in Management and Leadership at the Jyväskylä University School of Business and Economics, Finland. His research interests are innovation management, SMEs, entrepreneurship, and economic impact studies.

\section{Conflicts of interest}

The authors have no conflicts of interest

\section{Citation (APA Style)}

Littunen, H., Tohmo, T., \& Storhammar, E. (2021). Innovation among SMEs in Finland: The impact of stakeholder engagement and firm-level characteristics. Journal of Entrepreneurship, Management, and Innovation, 17(4), 157-196. https://doi.org/10.7341/20211746 